\title{
Zrównoważony rozwój jako nowa kategoria wartości w modzie luksusowej? Wyniki jakościowych badań międzynarodowych sprzedawców
}

\author{
Beata Stępień
}

\begin{tabular}{|c|c|}
\hline & A B STR A K T \\
\hline $\begin{array}{l}\text { Cel artykułu: Cele } \\
\text { nikowaniu zrówno } \\
\text { właścicieli marek i }\end{array}$ & $\begin{array}{l}\mathrm{n} \text { artykułu jest ukazanie przejawów i przyczyn rozbieżności w komu- } \\
\text { ważonego rozwoju (jako komplementarnej kategorii wartości) przez } \\
\text { sprzedawców w branży mody luksusowej. }\end{array}$ \\
\hline $\begin{array}{l}\text { Metodyka badań: } \\
\text { prowadzonych w } \\
\text { i Berlinie w sklepa }\end{array}$ & $\begin{array}{l}\text { Zastosowano badania jakościowe w formie utajonych zakupów prze- } \\
\text { latach 2017-2018 w czterech miastach: Singapurze, Dubaju, Paryżu } \\
\text { ch } 10 \text { światowych marek mody luksusowej. }\end{array}$ \\
\hline $\begin{array}{l}\text { Wyniki: Niskie zai } \\
\text { połączone z brak } \\
\text { niewielką wiedzą } \\
\text { kategorii wartośc }\end{array}$ & $\begin{array}{l}\text { teresowanie konsumentów kwestiami zrównoważonego rozwoju, } \\
\text { iem nacisku na wdrażanie tej idei w domach mody skutkuje } \\
\text { sprzedawców i komunikowaniem zrównoważonego rozwoju jako }\end{array}$ \\
\hline $\begin{array}{l}\text { Wkład i wartość o } \\
\text { wartości luksusu u } \\
\text { czonych lub Kanac } \\
\text { gorią nieistotną w } \\
\text { nie tej idei jest fun } \\
\text { czenia, jakie przyn }\end{array}$ & $\begin{array}{l}\text { odana: Znaczenie zrównoważonego rozwoju jako komplementarnej } \\
\text { zrasta wśród konsumentów pochodzących z Europy, Stanów Zjedno- } \\
\text { ly, podczas gdy dla odbiorców z Dalekiego Wschodu wciąż jest kate- } \\
\text { podejmowaniu decyzji zakupowych. Nacisk na krzewienie i wdraża- } \\
\text { kcją zarówno zainteresowania nią ze strony konsumentów, jak i zna- } \\
\text { iązuje do niej sama marka. }\end{array}$ \\
\hline Typ artykułu: & oryginalny artykuł badawczy \\
\hline Słowa kluczowe: & $\begin{array}{l}\text { zrównoważony rozwój; moda luksusowa; utajone zakupy; komuni- } \\
\text { kowanie wartości dla konsumenta; sprzedawcy luksusowej mody }\end{array}$ \\
\hline Kody JEL: & D11, D12 \\
\hline Artykuł nades & Artykuł zaakceptowano: 22 marca 2019 \\
\hline
\end{tabular}

\section{Sugerowane cytowanie:}

Stępień, B. (2019). Zrównoważony rozwój jako nowa kategoria wartości w modzie luksusowej? Wyniki jakościowych badań międzynarodowych sprzedawców. International Entrepreneurship Review (previously published as International Entrepreneurship / Przedsiębiorczość Międzynarodowa), 5(1), 39-56. https://doi.org/10.15678/IER.2019.0501.03 


\section{WPROWADZENIE}

Zrównoważony rozwój to idea coraz wyraźniej obecna w niemal we wszystkich sektorach gospodarki. Działalność firm na rzecz zrównoważonego rozwoju staje się normą, którą cenią i dostrzegają odbiorcy, traktując takie działania coraz częściej nie tyle jako dodatkowy atut, ale konieczny i wymagany społecznie sposób gospodarowania (Caniato, Caridi, Castelli, \& Golini, 2012; De Brito, Driesen, \& Rayp, 2008; Kirsi \& Lotta, 2011; Li, Zhao, Shi, \& Li, 2014; Seuring \& Goldbach, 2006; Tallontire, Rentsendorj, \& Blowfield, 2001).

Pojawia się jednak pytanie, na ile ta idea jest już obecna i wdrażana w biznesie, który przez wieki troszczył się przede wszystkim o najwyższą jakość i piękno wytwarzanych dóbr, nie dbając przy tym o humanitarny, czy środowiskowo neutralny sposób pozyskania materiałów, czy też redukcję nakładu pracy potrzebną do wykonania dzieł rzadkich, drogich i przeznaczonych dla nielicznych. Mowa tu o luksusie - kategorii dóbr i usług rzadkich, drogich, pięknych i niepotrzebnych, a symbolizujących bogactwo i przynależność do elitarnej grupy społecznej (Berry, 1994; Chandon, Laurent \& Valette-Florence, 2016; Kapferer \& Valette-Florence, 2018; Stępień, 2019; Wong, Chung \& Zaichkowsky, 1999).

Artykuł stanowi próbę odpowiedzi na to pytanie na przykładzie analizy działalności komunikacyjnej związanej z wdrażaniem idei zrównoważonego rozwoju w branży luksusowej mody. Aby sprawdzić, na ile zrównoważony rozwój faktycznie staje się elementem biznesu luksusu (tutaj mody) skonfrontowano publicznie dostępne informacje związane z wdrażaniem idei zrównoważonego rozwoju przez wybrane marki mody luksusowej z wiedzą i komunikowaniem tych działań przez sprzedawców. W celu uzyskania jak najbardziej wiarygodnych danych dotyczących tego, na ile zrównoważony rozwój jest kategorią wartości ważną dla (i przez to widoczną w działalności) domów mody i dla konsumentów, posłużono się metodą utajonych zakupów, przeprowadzonych w sklepach 10 marek na terenie czterech miast: Singapuru, Dubaju, Paryża i Berlina.

Artykuł jest skonstruowany w następujący sposób. Rozpoczyna go przedstawienie luksusu, jako dóbr społecznie upragnionych, choć moralnie potępianych i jednocześnie wytwarzanych niezgodnie z ideą zrównoważonego rozwoju. Kolejna część przedstawia informacje na temat deklarowanej przez wybrane marki luksusowej mody działalności związanej ze zrównoważonym rozwojem. Następnie omówiono wyniki badań - wywiadów ze sprzedawcami przeprowadzonych w formie utajonych zakupów na temat zrównoważonego rozwoju jako kategorii wartości ważnej (lub nieistotnej) dla samych marek, jak i dla konsumentów. Artykuł zakończono konkluzjami i wskazówkami o charakterze aplikacyjnym, związanymi z możliwością poprawy wizerunku biznesu luksusu jako zorientowanego prospołecznie i pro-środowiskowo.

\section{PRZEGLĄD LITERATURY}

\section{Luksus: przedmiot społecznego pragnienia i napiętnowania}

Studia dotyczące luksusu są toczącą się od tysiącleci debatą na temat moralnego wydźwięku konsumowania oraz odbioru i konsekwencji jego publicznej ekspozycji, a bazę osądów stanowią funkcjonujące w danym czasie społeczne kanony moralne i religijne (Berry, 1994; Cloutier, 2015). Napiętnowanie i zdecydowanie mniej liczne próby odczarowania luksusu koncentrowały się na sposobie jego konsumpcji i publicznej ekspozycji. 
W historycznym rysie moralnej oceny luksusu dominują dwa wątki:

- napiętnowanie ostentacyjnej konsumpcji niższych klas, nie uprawnionych do tego przywileju z racji miejsca w hierarchii społecznej wyznaczonej przez urodzenie;

- religijny nakaz życia w ubóstwie, nie obowiązujący jednak kręgów rządzących, dla których otaczanie się luksusem było legitymizacją potęgi państwa i kościoła.

Najstarsze ujęcia symboliki społecznej luksusu widoczne są już w pismach klasycznych filozofów. Sokrates postrzegał luksus jako konieczność publiczną; końcowy etap i efekt rozwoju społecznego, w którym te dobra służą ogółowi. Przeciwstawiał tak pojętemu luksusowi ludzką skłonność do hołdowania przyjemnościom cielesnym, a że te żądze są silniejsze u jednostki niż chęć służenia społeczeństwu przeto luksus, jako dobro prywatne, powinien podlegać limitowaniu i kontroli. Platon (w Republice, Miasto Świń) pisze, że gdy nie ma żadnych prawnych ograniczeń dla ludzkich pragnień, miasta przeradzają się w „tryphosa polis", będąc w ciągłej pogoni za luksusem i zaspokajaniem coraz to nowych, bardziej wyrafinowanych żądz (McKeen, 2004). Podobnie Arystoteles uważał, że życie w luksusie jest niegodne jednostki, bo nie przyczynia się do pomnażania dobrobytu społeczeństwa (Berry, 1994). Skala dychotomii pomiędzy głoszonymi poglądami, jak powinni postępować obywatele, a ich faktycznym zachowaniem, uwidoczniały ustawy zakazujące publicznej ekspozycji luksusowych strojów, biżuterii, lektyk, czy zakazy zbiorowego oddawania się uciechom podniebienia i innych zmysłów (Braund, 1994; Culham, 1982).

Legislacyjna walka państwa ze społecznym pragnieniem i publiczną ekspozycją luksusu trwała w Europie aż do XVII wieku ${ }^{1}$. Regulacje przeciwko zbytkowi miały przeciwdziałać nadmiernym wydatkom stanowiącym zagrożenie dla duszy, odwrócenie od Boga i psującym porządek publiczny. Luksus, jako miara wielkości i wspaniałości miał pozostać domeną nielicznych, uprzywilejowanych członków społeczeństwa i legitymizować ich wielkość i władzę (McNeil \& Riello, 2017).

Wczesny kapitalizm agrarny z XVII i XVIII wieku zbiegł się z tym, co Berry (1994) nazywa „odmoralizowaniem” luksusu (ss.169-73). Intensywne uprzemysłowienie, dynamiczny rozwój handlu połączony z pojawieniem się wczesnych form promocji sprzyjał wzrostowi konsumpcji dóbr luksusowych. Coraz szersze grono ludzi miało dostęp do wyrobów upiększających domostwa, a rozwój technologii rzemieślniczych pozwalał na produkcję na masową skalę i obniżenie cen. Bernard Mandeville, David Hume, Adam Smith², a później W. Sombart (patrz Franchetti, 2013; Mandeville, 1989; Marshall, 2000) dostrzegali użyteczną ekonomicznie stronę luksusu. Podkreślali, że dzięki rozwojowi tego biznesu coraz więcej ludzi ma pracę, co przyczynia się do rozwoju ekonomicznego, a samo upowszechnienie luksusu jest wyrazem ogólnego rosnącego dobrobytu społecznego. I choć z rewolucją przemysłową i początkiem kapitalizmu nie zaprzestano debaty o moralnym wydźwięku luksusu, to z pewnością jej ton uległ znacznemu złagodzeniu.

\footnotetext{
${ }^{1}$ Dla przykładu, rozporządzenie francuskiego króla Filipa II z 1279 roku zakazywało mieszczanom noszenia futer z popielic i gronostajów, drogich kamieni oraz diademów ze złota i srebra, a ustawa angielska z 1336 roku głosiła, że noszenie ubrań i futer importowanych spoza Anglii, Irlandii, Walii i Szkocji dozwolone jest tylko dla członków rodziny królewskiej, wysoko urodzonej szlachty i kleru. Włoskie ustawodawstwo z XVI wieku ograniczało konsumpcję zbytkownych tkanin, ubrań, potraw, wyposażenia wnętrz, czy środków transportu. Regulacje przewidywały system kar pieniężnych i cielesnych (np. publiczne batożenie) nie tylko dla konsumentów, ale też dla rzemieślników wytwarzających te dobra.

${ }^{2} \mathrm{~A}$. Smith nie był zwolennikiem luksusu, gdyż widział w nim pierwiastek demoralizujący, ale - podobnie jak Hume - dostrzegał w nim komponent innowacyjny i napędowy gospodarki.
} 
Pomimo skłonności klas uprzywilejowanych do otaczania się luksusem z racji urodzenia lub przedsiębiorczości (mowa tu głównie o rzemieślnikach, kupcach i bankierach), w większości społeczeństw przed-nowożytnych sztywna hierarchia społeczna nie wiązała się z drastyczną dychotomią wartości moralnych. Kumulacja bogactwa pozwalała wprawdzie uprzywilejowanym na otaczanie się luksusem, ale brakowało aprobaty do epatowania nim. Jak wskazuje Stearns (2006), aż do XVIII wieku w historii ludzkości widać dużą spójność w systemie wartości przed-nowożytnych społeczeństw, wyznaczanych przez obowiązki wobec państwa, ziemi i władcy oraz podporządkowanie życia doczesnego surowym nakazom religijnym. Religie zaś jednogłośnie - od chrześcijaństwa, przez islam, buddyzm, hinduizm aż do konfucjanizmu (raczej prądu filozoficznego niż religii) propagowały pokorę, cnotę i umiarkowanie w przejawianiu i zaspokajaniu potrzeb innych niż podstawowe.

\section{Współczesny moralny wydźwięk luksusu: luksus a społeczna równowaga}

Współcześnie ciężar ocen moralnych dotyczących konsumpcji luksusu przeniósł się na problem nierówności społecznych, wynikających z różnic w akumulacji kapitału. Poniżej poruszono jedynie niejednoznaczny związek luksusu ze stosunkowo nowym, choć coraz bardziej powszechnym, globalnym trendem dążenia do zrównoważonego rozwoju gospodarczego (ang. sustainability).

Według badań nad relacją między luksusem a zrównoważonym rozwojem, te dwa obszary wydają się wzajemnie wykluczać (Achabou \& Dekhili, 2013; Hilton, 2004; Janssen, Vanhamme, Lindgreen \& Lefebvre, 2013; Kapferer \& Michaut-Denizeau, 2013; Kapferer \& Valette-Florence, 2018; Slater, 1997). Jest kilka powodów, dla których luksus i zrównoważony rozwój mogą tworzyć oddzielne światy. W zrównoważonym podejściu głównym założeniem jest wykorzystanie zasobów w taki sposób, aby zapewnić maksymalną użyteczność przy minimalnych szkodach dla środowiska oraz dla obecnych i przyszłych pokoleń (Voyer \& Beckham, 2014; Yang, Han \& Lee, 2017). Z tego punktu widzenia produkcja i konsumpcja towarów luksusowych - w zasadzie niepotrzebna jest szkodliwa dla środowiska. Ograniczone zasoby planety są marnowane na produkcję czegoś, co zaspokaja wysublimowane pragnienia coraz większej, choć wciąż globalnie nielicznej grupy bogatych (Dion \& Borraz, 2017; Thach \& Olsen, 2006; Willems et al., 2012). Przedstawienie dóbr luksusowych jako niepotrzebnych, a ich konsumpcji jako rzucającej się w oczy, prowadzi jednak do moralnego potępienia takiego zachowania (Achabou \& Dekhili, 2013; Atwal \& Williams, 2009; Chevalier \& Mazzalovo, 2008; Janssen, Vanhamme, Lindgreen \& Lefebvre, 2013; Kapferer \& Bastien, 2009; Kapferer \& Michaut-Denizeau, 2013). Epatowanie bogactwem nie koresponduje z postawą dążącą do równoważenia warunków, w jakich ludzie żyją na świecie, zwłaszcza jeśli weźmiemy pod uwagę np. budowanie 5-gwiazdkowych hoteli w krajach o wysokim wskaźniku biedy. Samo istnienie luksusu w miejscach, gdzie poziom życia ludności jest niski, eksponuje społeczne kontrasty i zwiększa jego negatywne postrzeganie u tych, którzy są pozbawieni przyzwoitych warunków życia.

Prowadzi to do kolejnego powodu, dla którego luksus i idea zrównoważonego rozwoju są odrębnymi światami. Podczas gdy luksus może powodować napiętnowanie społeczne, to jednak sam zakup i korzystanie z niego wywołuje szereg pozytywnych odczuć i doświadczeń u konsumentów. Pragnienie epatowania bogactwem nie musi leżeć u podstaw tej przyjemności. Kupując dobra luksusowe, konsumenci chcą cieszyć się ich pięknem, kunsztem i ponadprzeciętną jakością materiałów. Sam proces zakupu też ma być przyjemnym 
doświadczeniem. Martwienie się o los planety zwyczajnie nie pasuje do zestawu cech tworzących przyjemną aurę (Kapferer \& Michaut-Denizeau, 2013).

Pomimo wspomnianych rozbieżności luksus nie jest zaprzeczeniem idei zrównoważonego rozwoju. Po pierwsze, dobra luksusowe są nadal stosunkowo rzadkie i kosztowne (Brooke, 2004; Kapferer \& Michaut-Denizeau, 2013; Tsai, 2005). Ich zakup, ze względu na cenę, jest wciąż ograniczony. Z tego powodu destrukcyjny wpływ tego sektora na środowisko nie jest tak duży, jak w przypadku produkcji towarów masowych. Po drugie, w sektorze luksusu korzystanie z zasobów naturalnych i wytwarzanie dóbr charakteryzuje się większą dbałością o jakość produkcji, a sposób pozyskania rzadkich materiałów do produkcji towarów luksusowych wydaje się być lepiej kontrolowany niż w przypadku firm produkujących dobra masowe, chociażby ze względu na groźbę utraty reputacji marki, jako najistotniejszego waloru marketingowego (De Pelsmacker, Driesen, \& Rayp 2003; Vermeir \& Verbeke, 2006). Gdyby rzeczywiste działania związane z produkcją wszystkich współczesnych dóbr luksusowych nadal pokrywały się z ich tradycyjnym wizerunkiem, konwergencja modeli zrównoważonego biznesu i luksusu byłaby większa. Sam fakt kontroli łańcuchów dostaw nie gwarantuje jednak, że powstałe w ten sposób towary będą przyjazne dla środowiska.

Wyniki dotychczasowych badań potwierdzają ambiwalentny związek między luksusem a zrównoważonym rozwojem w opiniach konsumentów. Luksus, oceniany jako kategoria semantyczna, kojarzy się raczej z niezrównoważonym niż zrównoważonym rozwojem. Natomiast już porównanie jakości i sposobów wytwarzania produktów luksusowych z ich masowymi odpowiednikami świadczy na korzyść luksusowego biznesu jako bliższego w swym działaniu idei zrównoważonego rozwoju (Janssen, Vanhamme, Lindgreen \& Lefebvre, 2013; Kapferer \& Michaut-Denizeau, 2013; Vermeir i Verbeke, 2006).

\section{Zrównoważony rozwój jako kategoria wartości: strategie komunikacyjne luksusowych domów mody}

Wiele badań pokazuje, że konsumenci cenią sobie korporacyjną odpowiedzialność za zrównoważony rozwój wprzęgniętą w strategie firm. Działania zgodne z ideą zrównoważonego rozwoju koncentrują się na zmniejszaniu zanieczyszczenia, świadomym wykorzystaniu zasobów naturalnych, zapewnieniu godnych warunków pracy i dbałości o lokalne społeczności i środowisko (Caniato, Caridi, Castelli, \& Golini, 2012; De Brito, Driesen, \& Rayp, 2008; Kirsi \& Lotta, 2011; Li, Zhao, Shi, \& Li, 2014; Seuring \& Goldbach, 2006; Tallontire, Rentsendorj, \& Blowfield 2001). Promowanie i wspieranie zrównoważonego rozwoju nie tylko nabiera znaczenia dla konsumentów, ale stanowi jeden z priorytetów przyjętych przez UE i organizacje międzynarodowe, takie jak OECD, ONZ, czy WTO.

Według De Brito, Driesen i Rayp (2008) oraz Caniato, Caridi, Castelli i Golini, (2009), w biznesie luksusu przesłankami do wdrażania zrównoważonych praktyk są koszty operacyjne, ryzyko, korzyści rynkowe i ograniczenia prawne. Przepisy dotyczące produkcji ograniczają emisję dwutlenku węgla, zanieczyszczenia powietrza i wody, co w połączeniu z katastrofalnym ekologicznym wizerunkiem np. przemysłu tekstylnego i mody stanowi zachętę do podejmowania działań przez firmy w tym obszarze. Konsekwentna realizacja zrównoważonych praktyk może działać jako atut dla marek, zwłaszcza w porównaniu z firmami, które wciąż niechętnie wprowadzają ten pomysł do swojego modelu biznesowego. 
Z publicznie dostępnych danych wynika, że dwa największe konglomeraty skupiające najbardziej znane globalne marki mody luksusowej - LVMH i Kering SA podejmują szereg działań w celu wdrożenia idei zrównoważonego rozwoju w modelach biznesowych wszystkich swoich członków. Biznes luksusu dostrzega upowszechniające się trendy konsumenckie i stara się uczynić ideę zrównoważonego rozwoju nową kategorią wartości mając świadomość, że coraz młodsze pokolenia konsumentów są przychylne (przynajmniej w sferze deklaracji) hołdowaniu tej ideologii (patrz np. Ramirez, 2019).

Zdecydowanie skuteczniejsza i bardziej kompleksowa strategia w tym zakresie jest realizowana przez Kering, który ogłosił nowy plan działań w ramach trzech filarów strategii 2025. To kolejno troska o wpływ na planetę, współpraca z długoterminowymi dostawcami i rozwój (Kering, n.d). Firma została uznana za jedną ze stu (47/100) firm najbardziej zaangażowanych w promowanie i wdrażanie idei zrównoważonego rozwoju na świecie i jest jedyną luksusową grupą wymienioną w 2017 roku w indeksie Dow Jones Sustainability Index (DJSI).

LVMH również realizuje ideę zrównoważonego, odpowiedzialnego rozwoju, chociaż zaczął publikować informacje na temat tej działalności znacznie później niż jego główny, choć mniejszy konkurent, Kering. W 2012 r. LVMH uruchomił program LIFE (Inicjatywa LVMH dla środowiska), aby zwiększyć efektywność środowiskową wszystkich członków Grupy. Ideą LIFE jest to, że każdy członek LVMH ustanawia swój własny plan działania w zakresie zrównoważonego rozwoju. Wśród celów LIFE są: poprawa ekologiczności produktów; zastosowanie najwyższych standardów środowiskowych w 70\% łańcuchach dostaw; poprawa tzw. efektywności środowiskowej ${ }^{3}$ wszystkich obiektów i sklepów o co najmniej $10 \%$ oraz zmniejszenie emisji CO2 ze zużycia energii o 25\% w porównaniu z 2013 r (LVMH, n.d.).

Intensywność działań, zarówno faktycznych, jak i komunikacyjnych dotyczących wdrażania idei zrównoważonego rozwoju jest jednak zróżnicowana jeśli chodzi o poszczególne marki mody luksusowej. Warto przy tym podkreślić, że nie można stawiać znaku równości pomiędzy informowaniem o tym, co się robi w ramach implementacji tej idei w model biznesu danej marki, a faktycznymi działaniami firm. Poniżej, w tabeli 1 przedstawiono publicznie dostępne informacje dotyczące działalności wybranych (i badanych później empirycznie, o czym mowa niżej) marek luksusowej mody, należących w dużej mierze do konglomeratów Kering i LVMH.

Z danych przytoczonych w tabeli 1 wynika, że zrównoważony rozwój jest ideą coraz bliższą biznesowi luksusu, który próbuje uczynić (i komunikować) te działania komplementarną wartością luksusu. Nawet jeśli zainteresowanie kwestiami zrównoważonego rozwoju wśród luksusowych konsumentów mody wciąż jest raczej wschodzącym niż widocznym trendem, to warto przytoczyć opinię François-Henri Pinault (CEO konglomeratu Kering), który w jednym ze swoich wywiadów powiedział: „Jeśli będziemy czekać, aż konsumenci będą nalegać na zrównoważony rozwój jako warunek zakupu, nic się nie wydarzy, od nas zależy, czy produkty środowiskowe staną się nową normą" (Paton, 2017).

\footnotetext{
${ }^{3}$ Efektywność środowiskowa - funkcjonowanie przy mniejszym obciążeniu środowiska
} 
Tabela 1. Działania na rzecz zrównoważonego rozwoju luksusowych marek odzieżowych - informacje ze stron internetowych i oficjalnie opublikowanych raportów

\begin{tabular}{|c|c|c|}
\hline $\begin{array}{l}\text { Przynale- } \\
\text { żność do }\end{array}$ & $\begin{array}{l}\text { Marka / ranking } \\
\text { „sustainability”* }\end{array}$ & $\begin{array}{c}\text { Funkcje zrównoważonego rozwoju w oficjalnej komunikacji w mediach } \\
\text { masowych }\end{array}$ \\
\hline $\begin{array}{l}\text { Kering: } \\
\text { Gucci } \\
\text { Group }\end{array}$ & $\begin{array}{l}\text { Bottega Veneta } \\
\text { Nie kla- } \\
\text { syfikowana }\end{array}$ & $\begin{array}{l}\text { Brak informacji na oficjalnej stronie, promowana jako tzw. cichy luksus, } \\
\text { który pokazuje osobowość, a nie logo (brak logo, cecha charaktery- } \\
\text { styczna marki - plecionka ze skóry, umieszczana w wielu wyrobach } \\
\text { w dyskretnych odsłonach). Informacje o marce i jej wysiłkach na rzecz } \\
\text { zrównoważonego rozwoju odzwierciedlone w raportach Kering. BW in- } \\
\text { tensywnie działa w sposób zrównoważony; 100\% identyfikowalności uży- } \\
\text { tej skóry, wyjątkowa ostrożność w stosowaniu materiałów we współ- } \\
\text { pracy z dostawcami, eliminacja zagrożeń chemicznych w produkcji itd. }\end{array}$ \\
\hline $\begin{array}{l}\text { Rodzina } \\
\text { Wertheim } \\
\text { er }\end{array}$ & \begin{tabular}{|l|} 
Chanel \\
Najniższy ranking \\
$(\mathrm{E}, 0 / 36)$ \\
\end{tabular} & Żadnych informacji na stronach i w raportach \\
\hline LVMH & $\begin{array}{l}\text { Dior } \\
E(5 / 36)\end{array}$ & $\begin{array}{l}\text { Ograniczone informacje na oficjalnej stronie internetowej. Dior wdraża } \\
\text { pewne środki mające na celu zmniejszenie wpływu na środowisko jego } \\
\text { materiałów opakowaniowych, angażuje się w wyrównywanie szans oraz } \\
\text { promowanie różnorodności i równości w miejscu pracy (w tym raport } \\
\text { dotyczący różnic w wynagrodzeniach kobiet i mężczyzn w } 2017 \text { r, the } \\
\text { Gender Pay Gap Report). }\end{array}$ \\
\hline $\begin{array}{l}\text { Kering; } \\
\text { Gucci } \\
\text { Group }\end{array}$ & $\begin{array}{l}\text { Gucci } \\
\text { ranking D } \\
(12 / 36)\end{array}$ & $\begin{array}{l}\text { Informacje obejmują zobowiązanie Gucci do: oszczędzania energii we } \\
\text { wszystkich sklepach, biurach, magazynach i łańcuchach dostaw Gucci; } \\
\text { optymalizacja dystrybucji za pomocą opakowań z certyfikowanych lasów } \\
\text { zarządzanych w sposób zrównoważony (ang. FSC); zmniejszenie zużycia } \\
\text { wody w całym łańcuchu dostaw; tworzenie materiałów przyjaznych dla } \\
\text { środowiska; zrównoważone pozyskiwanie i identyfikowalność materia- } \\
\text { łów }\end{array}$ \\
\hline $\begin{array}{l}\text { Rodzina } \\
\text { Hermes }\end{array}$ & $\begin{array}{l}\text { Hermes } \\
\text { (ranking E 3/36) }\end{array}$ & $\begin{array}{l}\text { Hermès dąży do ograniczenia emisji gazów cieplarnianych i wykorzysta- } \\
\text { nia energii odnawialnej oraz wdraża środki związane z produkcją odpa- } \\
\text { dów, wykorzystuje przede wszystkim skóry bydlęce i owcze pochodzące } \\
\text { wyłącznie z krajów europejskich. }\end{array}$ \\
\hline LVMH & $\begin{array}{l}\text { Loro Piana } \\
\text { Nie kla- } \\
\text { syfikowana }\end{array}$ & $\begin{array}{l}\text { Zrównoważony rozwój jako część filozofii marki. Na oficjalnej stronie in- } \\
\text { ternetowej można znaleźć informacje na temat pochodzenia surowców } \\
\text { i traktowania zwierząt, środowiska i współpracy z lokalnymi rolnikami oraz } \\
\text { długoterminowe programy ochrony w celu ochrony zwierząt i ich siedlisk. } \\
\text { Model organizacji, zarządzania i kontroli dot. m.in. dbałości o środowisko } \\
\text { oraz kodeks postępowania dostawcy oficjalnie opublikowane. }\end{array}$ \\
\hline LVMH & $\begin{array}{l}\text { Luis Vuitton } \\
\text { D (6/36) }\end{array}$ & $\begin{array}{l}\text { Zaangażowany w redukcję odpadów, emisję zielonych gazów, redukcję } \\
\text { opakowań oraz pełną certyfikację lub recykling. Wysiłki dot. zrównowa- } \\
\text { żonego rozwoju widoczne głównie w raportach LVMH, ale nie na oficjal- } \\
\text { nej stronie internetowej LV. }\end{array}$ \\
\hline $\begin{array}{l}\text { Prada } \\
\text { Group }\end{array}$ & $\begin{array}{l}\text { Prada } \\
\text { E (3/36) }\end{array}$ & $\begin{array}{l}\text { Brak informacji o szczegółowych działaniach na rzecz zrównoważonego } \\
\text { rozwoju. Na oficjalnej stronie Prada Group główne przesłanie dotyczy } \\
\text { działań na rzecz tworzenia piękna, wspierania kreatywności i zapewnie- } \\
\text { nia najwyższej jakości. Jedyne informacje o działaniach na rzecz zrówno- } \\
\text { ważonego dotyczą stosowania certyfikowanych lub poddanych recyklin- } \\
\text { gowi opakowań. Grupa przeznaczyła również około } 22 \text { mln EUR na } \\
\text { wsparcie działań społeczności lokalnych: promuje działania związane ze } \\
\text { sztuką i kulturą, inwestuje w wyjątkowe środowisko pracy, rozwijając } \\
\text { umiejętności rzemieślnicze wspierające marki Prada Group. }\end{array}$ \\
\hline
\end{tabular}




\begin{tabular}{|c|c|c|}
\hline $\begin{array}{l}\text { Przynale- } \\
\text { żność do }\end{array}$ & $\begin{array}{l}\text { Marka / ranking } \\
\text { „sustainability”* }\end{array}$ & $\begin{array}{l}\text { Funkcje zrównoważonego rozwoju w oficjalnej komunikacji w mediach } \\
\text { masowych }\end{array}$ \\
\hline $\begin{array}{l}\text { Kering; } \\
\text { Gucci } \\
\text { Group }\end{array}$ & $\begin{array}{l}\text { Saint Laurent } \\
\text { nie klasyfikowany }\end{array}$ & $\begin{array}{l}\text { Brak informacji na oficjalnej stronie internetowej SL, na stronach Kering } \\
\text { SA informacje o SL dotyczą wprowadzenia kompleksowego programu } \\
\text { zmniejszającego wpływ na środowisko sklepów SL (83\% do końca } 2014 \text { r., } \\
\text { z wyłączeniem domów towarowych). Marka poprawiła również zużycie } \\
\text { energii o prawie 40\% wdrażając wymagania LEED (ang. Leadership in En- } \\
\text { ergy and Environmental Design) w swoich praktykach. }\end{array}$ \\
\hline $\begin{array}{l}\text { Kering; } \\
\text { Gucci } \\
\text { Group }\end{array}$ & $\begin{array}{l}\text { Stella McCartney } \\
\text { C; 16/36); naj- } \\
\text { wyższy wynik w } \\
\text { rankingu luksuso- } \\
\text { wych marek mo- } \\
\text { dowych }\end{array}$ & $\begin{array}{l}\text { Promowanie zrównoważonego rozwoju jako ważnej cechy wizerunku } \\
\text { marki, wyraźnie widocznej na oficjalnej stronie: świat zrównoważonego } \\
\text { rozwoju Stelli. Szacunek dla natury, zwierząt, ludzi: produkowane w spo- } \\
\text { sób zrównoważony tkaniny, przejrzyste, starannie połączone i kontrolo- } \\
\text { wane łańcuchy dostaw, marka nie używa skór zwierząt itd. }\end{array}$ \\
\hline
\end{tabular}

* Raport dot. wdrożenia idei zrównoważonego rozwoju w biznesie luksusu (www.rankabrand.com) A - najwyższy, E - najniższy wskaźnik "sustainability"

Źródło: opracowanie własne na podstawie oficjalnych stron marek, raportów grup kapitałowych oraz informacji o każdej marce w połączeniu z hasłem „sustainability”.

\section{Komunikowanie wartości zrównoważonego rozwoju w branży luksusowej mody: rola sprzedawców}

Opisane wyżej rozważania pokazują dyskusyjny i niejednoznaczny związek pomiędzy społecznym odbiorem luksusu a jego sprzyjaniem idei zrównoważonego rozwoju. Jak wynika z najnowszego raportu, opublikowanego w 2019 r. przez Nosto (2019), ponad połowa konsumentów luksusu deklaruje, że kwestie związane z działaniami na rzecz zrównoważonego rozwoju są dla nich ważne w ocenie ogólnej wartości dóbr luksusowych, jakie nabywają. Warto jednak pamiętać o znaczącej dysproporcji pomiędzy deklaracjami konsumentów dotyczącymi sprzyjania idei zrównoważonego rozwoju, a ich faktycznymi wyborami (Davies, Lee \& Ahonkhai, 2012; Vermeir \& Verbeke 2006). Z drugiej strony luksus wciąż nie jest kojarzony z tą ideą, a głównym powodem tego stanu jest opisany wyżej, uwarunkowany historycznie społeczny odbiór moralny. Publiczna legitymizacja luksusu, jako kategorii dóbr pożądanych, ale jednak nie „niemoralnych” i przez to przyjaznych ludziom i środowisku wymaga zatem wykreowania takiego pozytywnego znaczenia. Rozbieżność między społecznym postrzeganiem luksusu a rosnącym zaangażowaniem właścicieli marek z biznesu luksusu w promowanie idei zrównoważonego rozwoju może być zniwelowana przez skuteczny przekaz takiej aktywności konsumentom. Podmiotami, które mogą zmniejszyć tę lukę, są nie tylko właściciele marek, ale też sprzedawcy - istotne ogniwa bezpośrednio komunikujące wartości dotyczące sprzedawanych dóbr potencjalnym odbiorcom.

Rola sprzedawców w procesie zakupu dóbr luksusowych polega bowiem nie tylko na zapewnieniu komfortu klientowi przy dostarczeniu jak największej ilości pozytywnych wrażeń, ale także informowaniu o filozofii, historii itd. leżącej u podstaw stworzenia danego produktu. Pod tym względem rola sprzedawcy sprowadza się do bycia ambasadorem marki dyskretnie komunikującym jej najważniejsze wartości i filozofię (Dion \& Borraz, 2017; Thach \& Olsen, 2006; Tynan, McKechnie, \& Chhuon 2010). Charakter informacji jest jednak ściśle uzależniony od postawy konsumenta: charakteru zadawanych pytań oraz chęci poznania historii powstania produktu lub samej marki. 
Biorąc powyżej opisane kwestie pod uwagę, założono, co następuje: komunikowanie działań dotyczących zrównoważonego rozwoju przez sprzedawców jest funkcją:

- zaangażowania marki w działania dotyczące zrównoważonego rozwoju,

- zainteresowania konsumentów kwestiami zrównoważonego rozwoju, a jego poziom jest z kolei zależny od kraju, z którego pochodzą konsumenci luksusu i skali rozpowszechnienia tej ideologii w miejscu ich stałego zamieszkania.

Poprzez zaangażowanie marki w ideę zrównoważonego rozwoju rozumie się przy tym nie tylko komunikowanie w domenie społecznej o takiej aktywności, ale rzeczywistą realizację tej idei odzwierciedloną np. w przekonaniu i wiedzy sprzedawców na ten temat.

\section{METODYKA BADAWCZA}

\section{Utajone zakupy}

Przedmiotem badań, prowadzonych w sklepach z luksusową modą na terenie Berlina, Paryża, Dubaju i Singapuru była identyfikacja treści i sposobu komunikacji przez sprzedawców znaczenia określonych składników wartości związanych z samym produktem lub procesem tworzenia czy użytkowania dóbr luksusowych określonej marki. Przyjęto założenie, że sprzedawcy w sklepach z luksusową modą, otrzymując wynagrodzenie w postaci prowizji od wartości zakupów dokonanych przez konsumentów, będą skłonni do posługiwania się w rozmowach takim zestawem informacji i zachęt które, choć dopasowane do konsumenta, okazują się skuteczne: kończą się zakupami. Zbadano, w jakim stopniu sprzedawcy komunikują te składniki wartości luksusu, które odwołują się do etycznej i zrównoważonej produkcji i konsumpcji w porównaniu z innymi jej komponentami: estetycznymi, funkcjonalnymi, społecznymi, czy hedonicznymi.

Badania przeprowadzono w latach 2017 i 2018 w sklepach z luksusową modą marek przedstawionych w tabeli 2, w której wskazano też lokalizację sklepów. Badania przeprowadzono w języku angielskim, francuskim i niemieckim. Choć terenem badań były cztery miasta w różnych krajach (Singapur, Niemcy, Francja, Zjednoczone Emiraty Arabskie), to narodowość sprzedawców nie zawsze odpowiadała miejscu, w którym pracowali. Największe rozbieżności zanotowano w Dubaju i Singapurze. Rozmówcami byli Niemcy, Francuzi, Tajowie, Malezyjczycy, Singapurczycy, Chińczycy, Anglicy i Kostarykańczycy.

Badania miały formę utajonych zakupów -podczas zbierania danych nie ujawniono celu wizyt w sklepach, zrobiono to na końcu i poproszono o zgodę na anonimowe wykorzystanie zebranych informacji. Nie zanotowano żadnej odmowy.

Szczegółowy protokół pytań związanych ze składnikami komponentu wartości dotyczącego zrównoważonego rozwoju opisano niżej, przy okazji omawiania wyników badań, w legendzie tabeli 3. Pytania, obok zwykłych próśb o dostarczenie określonych produktów do przymiarki, dotyczyły m.in. pochodzenia materiałów, sposobu ich produkcji i kontroli, charakteru szkoleń sprzedawców, kwestii opakowań, zużycia energii itd.

Badania przeprowadzono w czterech miastach: Dubaju, Singapurze, Paryżu i Berlinie. Wybór tych miast nie był przypadkowy. Singapur jest jednym z najbardziej rozwiniętych krajów świata, popularnym celem turystów i bazą wielu międzynarodowych korporacji. Dubaj to miasto, które chce zaskoczyć świat swoim architektonicznym rozmachem i nagromadzeniem atrakcji. Najwyższe budynki, spektakularne parki rozrywki, najwięk- 
sze i najnowocześniejsze domy handlowe wpisują się we wszechobecny i publicznie demonstrowany, ostentacyjny luksus. Paryż jest kolebką światowego luksusu. Produkty znanych i cenionych marek, takich jak Hermes, Dior, Chanel lub YSL (obecnie Saint Laurent), są tam nadal produkowane. Miasto jest uosobieniem najwyższej klasy architektury historycznej, sztuki, łącząc urok miejskiego piękna z nagromadzeniem najbardziej prestiżowych sklepów i restauracji. Podobnie jak Singapur, Dubaj i Berlin, Paryż jest zamieszkały przez niemal wszystkie narodowości świata. Berlin nie może być zaliczany do jednej z europejskich stolic mody luksusowej (takich jak Paryż, Mediolan czy Londyn), ale jest stolicą Niemiec; największej gospodarki w Unii Europejskiej.

Tabela 2. Utajone zakupy - wywiady ze sprzedawcami wybranych marek luksusowej mody w określonych lokalizacjach

\begin{tabular}{|l|c|c|c|c|}
\hline \multicolumn{1}{|c|}{ Marka } & Singapur* & Dubaj** & Paryz*** & Berlin**** \\
\hline Bottega Veneta & $\mathrm{x}$ & $\mathrm{x}$ & $\mathrm{x}$ & $\mathrm{x}$ \\
\hline Chanel & $\mathrm{x}$ & $\mathrm{x}$ & $\mathrm{x}$ & $\mathrm{x}$ \\
\hline Dior & $\mathrm{x}$ & $\mathrm{x}$ & $\mathrm{x}$ & $\mathrm{x}$ \\
\hline Gucci & $\mathrm{x}$ & $\mathrm{x}$ & $\mathrm{x}$ & $\mathrm{x}$ \\
\hline Hermes & $\mathrm{x}$ & brak sklepu w Dubai Mall & $\mathrm{x}$ & brak sklepu \\
\hline Loro Piana & $\mathrm{x}$ & $\mathrm{x}$ & $\mathrm{x}$ & $\mathrm{x}$ \\
\hline LV & $\mathrm{x}$ & $\mathrm{x}$ & $\mathrm{x}$ & $\mathrm{x}$ \\
\hline Prada & $\mathrm{x}$ & nie zbadano & $\mathrm{x}$ & $\mathrm{x}$ \\
\hline Saint Laurent & $\mathrm{x}$ & $\mathrm{x}$ & nie zbadano \\
\hline Stella McCartney & & $\mathrm{x}$ & $\mathrm{x}$ \\
\hline
\end{tabular}

* Orchard Rd, Marina Bay; ** Dubai Mall; *** Galeries Lafayette, Av. Montaigne, Champs Elysees **** KDW, Kurfurstendamm

Źródło: opracowanie własne.

\section{WYNIKI BADAŃ}

Ze względu na liczbę wywiadów (48), w tabeli 3 zbiorczo przedstawiono informacje o składnikach propozycji wartości dóbr związanych ze zrównoważonym rozwojem, najczęściej komunikowanych przez sprzedawców. Tabela przedstawia skwantyfikowaną ocenę odpowiedzi sprzedawców z markowych sklepów w taki sposób, aby pokazać poziom szczegółowości i charakteru odpowiedzi w czterech obszarach: (A) działania marki w celu zmniejszenia wpływu sklepów na środowisko, (B) wiedzy na temat pochodzenia i metody pozyskiwania materiałów, (C) wiedzy na temat kontroli i przejrzystości łańcucha dostaw oraz (D) wiedzy na temat kraju produkcji. Kwantyfikacja to wynik ilości i stopnia szczegółowości udzielanych przez sprzedawców informacji na temat poszczególnych działań marki w poszczególnych obszarach związanych ze zrównoważonym rozwojem.

Wyniki wywiadów przeprowadzonych w formie utajonych zakupów świadczą o ogólnie niskiej świadomości sprzedających na temat działań dotyczących zrównoważonego rozwoju podejmowanych przez marki, które sprzedawcy oferują. Różnice w świadomości na temat pro-środowiskowych i prospołecznych działań firm objawiają się następująco. Sprzedawcy posiadają relatywnie najmniejszą ilość informacji dotyczącą wkładu sklepów w zmniejszenie śladu środowiskowego, dysponując jednocześnie największą wiedzą na temat kraju produkcji sprzedawanych towarów. 
Tabela 1. Zakres i stopień szczegółowości informacji udzielanych przez sprzedawców luksusowej mody na temat zaangażowania marek w zrównoważony rozwój

\begin{tabular}{|c|c|c|c|c|}
\hline Marka & Singapur* & Dubaj** & Paryż*** & Berlin**** \\
\hline Bottega Veneta & $\begin{array}{l}A-1 \\
B-3 \\
C-4 \\
D-5\end{array}$ & $\begin{array}{l}A-0 \\
B-1 \\
C-3 \\
D-4\end{array}$ & $\begin{array}{l}A-1 \\
B-3 \\
C-4 \\
D-5\end{array}$ & $\begin{array}{l}A-1 \\
B-4 \\
C-4 \\
D-5\end{array}$ \\
\hline Chanel & $\begin{array}{l}A-0 \\
B-2 \\
C-1 \\
D-4\end{array}$ & $\begin{array}{l}A-0 \\
B-2 \\
C-1 \\
D-3 \\
\end{array}$ & \begin{tabular}{|l}
$A-1$ \\
$B-2$ \\
$C-3$ \\
$D-4$ \\
\end{tabular} & $\begin{array}{l}A-1 \\
B-2 \\
C-2 \\
D-4 \\
\end{array}$ \\
\hline Dior & $\begin{array}{l}A-1 \\
B-2 \\
C-2 \\
D-3\end{array}$ & $\begin{array}{l}A-0 \\
B-2 \\
C-1 \\
D-2\end{array}$ & $\begin{array}{l}A-1 \\
B-3 \\
C-3 \\
D-4\end{array}$ & $\begin{array}{l}A-1 \\
B-3 \\
C-2 \\
D-4\end{array}$ \\
\hline Gucci & $\begin{array}{l}A-1 \\
B-2 \\
C-3 \\
D-4\end{array}$ & $\begin{array}{l}A-0 \\
B-1 \\
C-2 \\
D-3\end{array}$ & $\begin{array}{l}A-1 \\
B-2 \\
C-3 \\
D-4\end{array}$ & $\begin{array}{l}A-1 \\
B-2 \\
C-3 \\
D-5 \\
\end{array}$ \\
\hline Hermes & $\begin{array}{l}A-0 \\
B-2 \\
C-1 \\
D-4\end{array}$ & $\begin{array}{l}A-0 \\
B-1 \\
C-0 \\
D-4\end{array}$ & $\begin{array}{l}A-0 \\
B-2 \\
C-2 \\
D-4\end{array}$ & $\begin{array}{l}A-0 \\
B-2 \\
C-2 \\
D-4\end{array}$ \\
\hline Loro Piana & \begin{tabular}{|l}
$A-1$ \\
$B-4$ \\
$C-5$ \\
$D-5$ \\
\end{tabular} & - & $\begin{array}{l}A-1 \\
B-4 \\
C-5 \\
D-5 \\
\end{array}$ & - \\
\hline$L V$ & \begin{tabular}{|l}
$A-0$ \\
$B-2$ \\
$C-2$ \\
$D-4$ \\
\end{tabular} & $\begin{array}{l}A-0 \\
B-1 \\
C-2 \\
D-4 \\
\end{array}$ & $\begin{array}{l}A-1 \\
B-3 \\
C-3 \\
D-5 \\
\end{array}$ & $\begin{array}{l}A-1 \\
B-3 \\
C-3 \\
D-4 \\
\end{array}$ \\
\hline Prada & $\begin{array}{l}A-0 \\
B-1 \\
C-1 \\
D-3\end{array}$ & $\begin{array}{l}A-0 \\
B-1 \\
C-1 \\
D-3 \\
\end{array}$ & $\begin{array}{l}A-0 \\
B-2 \\
C-2 \\
D-4 \\
\end{array}$ & $\begin{array}{l}A-0 \\
B-2 \\
C-2 \\
D-4 \\
\end{array}$ \\
\hline Saint Laurent & $\begin{array}{l}A-0 \\
B-2 \\
C-2 \\
D-4\end{array}$ & $\begin{array}{l}A-0 \\
B-1 \\
C-2 \\
D-4\end{array}$ & $\begin{array}{l}A-1 \\
B-2 \\
C-3 \\
D-5\end{array}$ & $\begin{array}{l}A-1 \\
B-2 \\
C-3 \\
D-4\end{array}$ \\
\hline Stella McCartney & $\begin{array}{l}A-1 \\
B-3 \\
C-3 \\
D-3\end{array}$ & - & $\begin{array}{l}A-1 \\
B-3 \\
C-3 \\
D-4\end{array}$ & - \\
\hline
\end{tabular}

Legenda: A - wiedza na temat zmniejszania śladu środowiskowego przez sklepy: oszczędności na zużyciu energii w sklepach; FSC lub opakowanie z recyklingu; B - wiedza o pochodzeniu materiałów: futro, skóra, bawełna, wełna i stopień ich organicznego charakteru; C - wiedza na temat przejrzystości i zakresu kontroli łańcucha dostaw; dbałość o dobro pracowników i zwierząt; D - wiedza na temat miejsca produkcji odzieży i odzieży; 0 - brak informacji; 1 - bardzo ograniczona; bardzo ogólna informacja; 2 - ograniczona, ogólna informacja; 3 - niektóre, szczegółowe informacje; 4 - szczegółowa, choć nie wyczerpująca wiedza na dany temat; 5 - rozległa wiedza na dany temat Lokalizacja sklepów * Orchard Road, Marina Bay; ${ }^{* *}$ Dubai Mall; ${ }^{* * *}$ Galeries Lafayette, Avenue Montaigne, Champs Elysées; ${ }^{* * *}$ KDW, Kurfürstendamm.

Źródło: opracowanie własne. 
Rysunek 1 ilustruje zróżnicowanie i zakres informacji udzielanych w poszczególnych sklepach dotyczących działań i aktywności marek w obszarze zrównoważonego rozwoju.

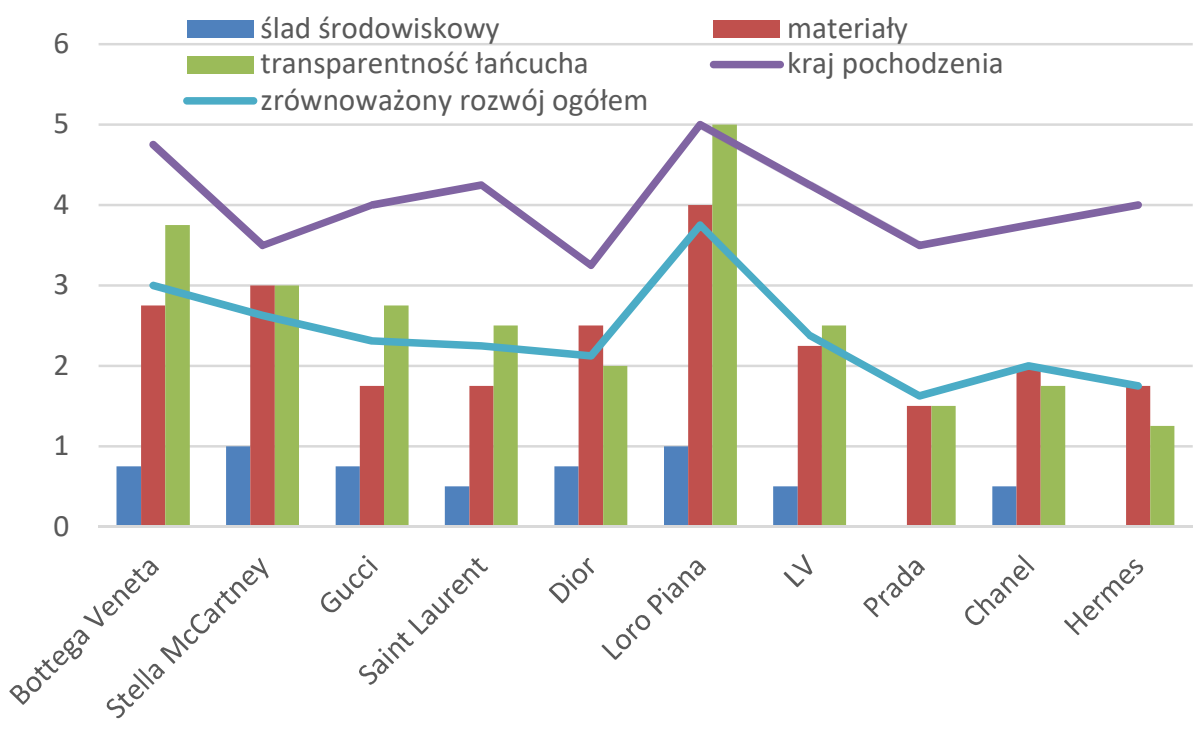

Rysunek 1. Skala informacji dotyczących poszczególnych działań w obszarze zrównoważonego rozwoju w sklepach badanych marek Źródło: opracowanie własne.

Wielu sprzedawców przyznało, że pytania o miejsce produkcji są najczęściej zadawane przez konsumentów. W ich opinii zainteresowanie krajem produkcji nie wynika jednak z troski o przejrzystość łańcucha dostaw. Podstawą tego zainteresowania jest uzyskanie pewności, że produkt jest autentyczny. Jak zauważyła sprzedawczyni w Gucci w Singapurze, chińscy konsumenci mają podstawy, aby obawiać się o autentyczność towarów, ponieważ wiele podrabianych produktów sprzedawanych jest pod logo Gucci w Chinach (Mozur, 2017). Sprzedawcy LV, Dior i Prada w Dubaju również mieli podobne obserwacje.

Przed badaniem zakładano też, że zainteresowanie konsumentów kwestiami zrównoważonego rozwoju może być większe w przypadku zakupów produktów luksusowych dla dzieci. Badania nie potwierdzają tego przypuszczenia. W sklepach Hermes w Dubaju i Singapurze, pomimo wyszukiwania informacji w wewnętrznych bazach danych, nie można było uzyskać odpowiedzi na pytanie o pochodzenie i atesty tekstyliów użytych do produkcji odzieży dziecięcej. W Baby Dior w Singapurze sprzedawczyni przyznała, że jedyną rzeczą, która posiada certyfikat ekologiczny w sklepie jest pluszowa zabawka królika wykonana z prawdziwego futra. Jej odpowiedź na pytanie: „Dlaczego nie można kupić ubrań z certyfikowanych materiałów ekologicznych w Baby Dior?” było symptomatyczne: „Tkaniny ekologiczne są bardzo kosztowne, nie możemy sobie pozwolić na ich użycie".

Porównanie zakresu i stopnia szczegółowości informacji komunikowanych na stronach internetowych marek z tym co komunikowali sprzedawcy podczas utajonych zakupów wskazuje, że jedynie trzy na dziesięć analizowanych marek prowadzą spójną politykę informacyjną dotyczącą zrównoważonego rozwoju w różnych kanałach (np. na oficjalnych 
stronach internetowych i w sklepach). Są to Loro Piana, LV i Saint Laurent, przy czym tylko Loro Piana rzeczywiście komunikuje swoje zaangażowanie na rzecz zrównoważonego rozwoju, podczas gdy LV i Saint Laurent są komunikacyjnie konsekwentni jeśli chodzi o ich niewielkie zaangażowanie $w$ tym obszarze.

Loro Piana jest marką, której głównym założeniem jest tworzenie ubrań i akcesoriów przy jednoczesnym poszanowaniu środowiska i wspieraniu lokalnych społeczności z terytorium pochodzenia materiału. Mimo to, odpowiedź na pytanie o pochodzenie futra szynszyli używanego do wykończenia ubrań brzmiała: „Nie znam jego pochodzenia, ale nie zabijamy ich sami".

Największe rozbieżności pomiędzy tym, co jest komunikowane w przestrzeni internetowej, a wiedzą i tendencją do komunikowania zaangażowania marki w zrównoważony rozwój w sklepach można zaobserwować w trzech markach: Bottega Veneta, Chanel i Stella McCartney. Podczas gdy w sklepach Chanel i Bottega Veneta sprzedawcy mówią więcej o zaangażowaniu marki w zrównoważony rozwój niż sama marka oficjalnie komunikuje, w przypadku Stelli McCartney jest odwrotnie: sprzedawcy niewiele wiedzą na temat konkretnych działań marki w tym obszarze poza przekonaniem, że jest to ważny element tworzenia wartości.

W Bottega Veneta, niezależnie od miasta, sprzedający podkreślali dbałość marki nie tylko o cały proces pozyskiwania materiałów, produkcję i dystrybucję, ale także o staranne szkolenie sprzedawców w tym zakresie. Sprzedawca tej marki w Singapurze z dumą podkreślał, że częścią jego szkolenia była wizyta we Florencji, gdzie miał możliwość szczegółowego poznania, jak duże znaczenie marka przywiązuje do wyboru dostawców, jakości surowców i kontroli produkcji.

Ze względu na zaangażowanie Stelli McCartney w zrównoważony rozwój oczekiwano, że wiedza sprzedawców na temat tego obszaru będzie największa, a odsetek konsumentów pytających o te kwestie najwyższy. Jednak tak nie było. Na pytanie, ilu klientów jest zainteresowanych różnymi obszarami zrównoważonego rozwoju, sprzedawcy odpowiedzieli, że jest to bardzo mała grupa. Średnio jeden na 20 konsumentów pyta o certyfikaty ekologiczne lub pochodzenie materiałów. Na prośbę o wyjaśnienie tego braku zainteresowania, sprzedawczyni w Singapurze (Stella McCartney Kids, Marina Bay) odpowiedziała: „Z tego, co obserwuję, konsumenci są głównie zainteresowani projektem, a następnie ceną, a w znacznie mniejszym stopniu wszystkimi pozostałymi kwestiami. Niektórzy konsumenci znają markę i jej filozofię i wiedzą, że marka gwarantuje zrównoważone pozyskiwanie materiałów i produkcję ubrań".

Ogólnie niską wiedzę na temat zrównoważonego rozwoju wykazali sprzedawcy marek Prada, Hermes, Dior i Louis Vuitton. W żadnym ze sklepów nie było szczegółowych informacji na temat: pochodzenia materiałów, hodowli zwierząt czy pozyskiwania surowców organicznych. Zapytany o zakres kontroli łańcucha dostaw sprzedawca w Hermes w Dubaju odpowiedział: „Oczywiście, że kontrolujemy je ... w określony sposób”.

W sklepie Prada w Singapurze na pytanie, skąd pozyskiwane są pióra dzikiego indyka użytego do uszycia kurtki, sprzedawczyni odpowiedziała, że nie wie, ale prawdopodobnie nie powinno to mieć znaczenia, ponieważ nie ma rozmiaru kurtki, o którą proszę. Sprzedawcy nie byli również w stanie odpowiedzieć na pytania o pozyskiwanie skóry używanej do produkcji butów i torebek. 
Niski poziom wiedzy na temat zrównoważonego rozwoju wśród sprzedawców tych marek może wynikać z ich popularności. Zgłaszane zapotrzebowanie na te produkty jest w pewnym sensie wytłumaczeniem ignorancji sprzedawców w kwestiach, które wydają się mało interesujące i nieistotne dla ich konsumentów.

Najmniejszą świadomość/ komunikację działań zrównoważonych firm wykazali sprzedający w Dubaju, a największą w Paryżu i Berlinie. Konsumenci ogólnie rzadko zadają pytania, które wskazują na ich zaangażowanie w kwestie ochrony środowiska lub promowanie zrównoważonego rozwoju, ale częściej pojawiają się one w sklepach europejskich niż azjatyckich. Sprzedawcy dość jednogłośnie podkreślali, że zainteresowanie kwestiami ekologicznymi, środowiskowymi i materiałowymi jest wyłaniającą się, ale rosnącą tendencją i częściej wyrażają ją mieszkańcy Europy, Stanów Zjednoczonych, Kanady i Australii. W Dubaju największą grupę nabywców stanowią mieszkańcy regionu Zatoki Perskiej i Chin a w Singapurze to Chińczycy. Ci ostatni konsumenci - zgodnie z oświadczeniami sprzedawców - nie są zainteresowani kwestiami zrównoważonego rozwoju. Wyższy poziom zainteresowania europejskich konsumentów zrównoważonym rozwojem powoduje również większą wiedzę handlowców w tym zakresie. Pytania o pochodzenie materiałów, stopień przejrzystości łańcucha dostaw, a nawet zaangażowanie sklepów w redukcję zużycia energii lub opakowań, nie zaskakują ich i są w stanie odpowiedzieć na nie szczegółowo.

\section{PODSUMOWANIE}

Rozbieżność między pojęciem luksusu a zrównoważonym rozwojem, choć głęboko, bo historycznie zakorzeniona w opinii publicznej, może zostać zrównoważona poprzez zaangażowanie przedsiębiorstw z tej branży w promowanie idei zrównoważonego rozwoju w ramach całego łańcucha wartości. Włączenie idei zrównoważonego rozwoju do strategii firm z branży mody luksusowej jest już faktem, choć niektóre domy mody nadal pozostają w tyle za tym trendem. O podejmowaniu coraz większych wysiłków mających na celu połączenie zrównoważonego rozwoju z filozofią biznesu luksusowej mody świadczą nie tylko informacje na oficjalnych stronach internetowych, czy w upublicznionych raportach, ale także aktywność w tym obszarze potwierdzona przez niezależne organizacje.

Działalność luksusowych domów mody obejmująca zmniejszenie negatywnego wpływu na środowisko, dobrostan zwierząt i życie ludzi wymaga intensyfikacji działań komunikacyjnych mających na celu złagodzenie wizerunku luksusu jako biznesu promującego nierówności społeczne i wykorzystującego ograniczone zasoby naturalne aby zaspokajać kaprysy małej grupy bogatych ludzi. Chociaż intensywna promocja działań prospołecznych przez przedsiębiorstwa może przynieść odwrotny skutek i wzbudzić wątpliwości co do motywów (Coombs \& Holladay, 2002), to należy odróżnić ostentacyjne informowanie od jego braku. Podczas gdy Kotler i Lee (2008) proponują firmom minimalny zakres komunikacji na temat działań dla dobra publicznego sugerując, aby to inni o tym mówili, Van de Ven, (2008) i Davies Lee i Ahonkhai (2012) udowadniają, że brak komunikacji w tym obszarze naraża przedsiębiorstwa na antyspołeczny wizerunek.

Sprzedawcy są ważną grupą, która może przyczynić się do krzewienia informacji o rosnącym zaangażowaniu sektora luksusu w zrównoważony rozwój. Jednakże ich rola jako ambasadorów marki w promowaniu idei zrównoważonego rozwoju nie jest wystarczająco wykorzystywana. 
Zaprezentowane wyniki badań wyraźnie pokazują, że koncepcja zrównoważonego rozwoju wciąż nie jest ważną składową propozycji wartości dóbr luksusowych dla konsumentów, a konsekwencją braku zainteresowania ze strony odbiorców jest niska świadomość sprzedawców w tym zakresie. Ograniczone zainteresowanie konsumentów zrównoważonym rozwojem skutkuje ogólnie niewielką wiedzą sprzedawców na temat tych działań i tym samym jej komunikowaniem, nie mówiąc już o promowaniu tej kategorii wartości.

Z przeprowadzonych badań wynika też, że zainteresowanie zrównoważonym rozwojem jako elementem biznesu wpływającym na decyzje zakupowe jest funkcją rozwoju społeczno - gospodarczego kraju, z którego pochodzą konsumenci. Należy się też w tym miejscu zgodzić z opinią François-Henri Pinault (CEO Kering Group), że istotną rolą biznesu luksusu może być propagowanie tej idei wśród bogatej, globalnej grupy odbiorców, bowiem to motywacje leżące u podstaw ich decyzji zakupowych stanowią podstawę do naśladownictwa dla mniej uprzywilejowanych materialnie grup społecznych. Aby jednak takie rozprzestrzenianie zrównoważonego rozwoju jako elementu wartości dóbr luksusowych mogło się zakorzenić w umysłach i sercach konsumentów na całym świecie, niezbędne jest uzyskanie spójności pomiędzy strategią komunikacyjną (chodzi tu o sprzedawców) i faktycznie realizowaną.

Firmy, które już stosują filozofię zrównoważonego rozwoju w swojej strategii, budują przewagę konkurencyjną przyszłości. Warto jednak, obok tych niezbędnych wysiłków, położyć nacisk na lepszą edukację sprzedawców omawianym obszarze, aby mogli oni promować nowy, zrównoważony luksus w umiejętny i subtelny sposób.

\section{LITERATURA}

Achabou, M.A. \& Dekhili, S. (2013). Luxury and sustainable development: Is there a match?. Journal of Business Research, 66(10), 1896-1903. http://doi.org/10.1016/j.jbusres.2013.02.011

Atwal, G. \& Williams, A., (2009). Luxury brand marketing - The experience is everything!. Journal of Brand Management, 16(5-6), 338-346.

Berry, C. (1994). The idea of luxury: A conceptual and historical investigation. Cambridge, UK: Cambridge University Press.

Braund, D. (1994). The luxuries of Athenian democracy. Greece \& Rome, 41(1), 41-48.

Brooke, S. (2004, January 17). Luxuries ain't what they used to be. Now the high street is full of designers labels and glittering prices, does anything count as exclusive. The Daily Telegraph, s. 4.

Caniato, F., Caridi, M., Castelli, C. \& Golini, R. (2009). A contingency approach for SC strategy in the Italian luxury industry: do consolidated models fit?. International Journal of Production Economics, 120(1), 176-189.

Caniato, F., Caridi, M., Crippa, L., \& Moretto, A. (2012). Environmental sustainability in fashion supply chains: An exploratory case based research. International Journal of Production Economics, 135, 659-670.

Chandon, J.L., Laurent, G. \& Valette-Florence, P. (2016). Pursuing the concept of luxury: Introduction to the JBR Special Issue on "Luxury Marketing from Tradition to Innovation." Journal of Business Research, 69(1). http://doi.org/10.1016/j.jbusres.2015.08.001

Chevalier, M. \& Mazzalovo, G. (2008). Luxury brand management: A World of Privilege. Singapore: Wiley. Cloutier, D. (2015). The Vice of Luxury: Economic Excess in a Consumer Age. Georgetown University Press. 
Coombs, W.T. \& Holladay, S.J. (2002). Helping crisis managers protect reputational assets: Initial tests of the situational crisis communication theory. Management Communication Quarterly, 16(2), 165-186.

Culham, P. (1982). The Lex Oppia, Latomus, 41(4), 786-793.

Davies, I.A., Lee, Z.I. \& Ahonkhai, I. (2012). Do consumers care about ethical-luxury?. Journal of Business Ethics, 106(1), 37-51.

De Brito, M., Carbone, V. \& Blanquart, C. (2008). Towards a sustainable fashion retail supply chain in Europe: organisation and performance. International Journal of Production Economics, 114(2), 534-553.

De Pelsmacker, P., Driesen, L. \& Rayp G. (2003). Are fair trade labels good business? Ethics and coffee buying intentions. Ghent: Working Paper Ghent University Faculty of Economics and Business Administration.

Dion, D. \& Borraz, S. (2017). Managing status: How luxury brands shape class subjectivities in the service encounter. Journal of Marketing, 81(5), 67-85.

Franchetti, C. (2013). A reconsideration of Werner Sombart's Luxury and capitalism. International Review of Social Sciences and Humanities, 5(2), 135-139.

Hilton, M. (2004). The Legacy of Luxury: Moralities of Consumption Since the 18th Century. Journal of Consumer Culture, 4(1), 101-123. doi: 0.1177/14695405040409060167-4544.

Janssen, C., Vanhamme, J., Lindgreen, A. \& Lefebvre, C. (2013). The catch-22 of responsible luxury: effects of luxury product characteristics on consumers' perceptions of fit with corporate social responsibility. Journal of Business Ethics, 119(1), 45-57.

Kapferer, J.-N. \& Bastien, V. (2009). The specificity of luxury management: Turning marketing upside down. Journal of Brand Management, 16(5-6), 311-322.

Kapferer, J.-N. \& Michaut-Denizeau, A. (2013). Is Luxury Compatible with Sustainable Development: the consumer viewpoint. Journal of Brand Management, 21(I), 1-22. doi:10.1057/bm.2013.19

Kapferer, J.-N. \& Valette-Florence, P. (2018). The impact of brand penetration and awareness on luxury brand desirability: A cross country analysis of the relevance of the rarity principle. Journal of Business Research, 83, 38-50.

Kering (n.d). Pozyskano z http://www.kering.com/en/sustainability_dostęp 13.06.2018).

Kirsi, N.A. \& Lotta, H.B. (2011). Emerging design strategies in sustainable production and consumption of textiles and clothing. Journal of Cleaner Production, 19, 1876-1883.

Kotler, P., Lee, N. (2008). Corporate social responsibility: Doing the most good for your company and your cause. John Wiley \& Sons.

Li, Y., Zhao, X., Shi, D. \& Li, X. (2014). Governance of sustainable supply chains in the fast fashion industry. European Management Journal, 32(5), 823-836. http://doi.org/10.1016/j.emj.2014.03.001

LVMH (n.d). Pozyskano z https://www.Ivmh.com/group/lvmh-commitments/environment/_dostęp 13.06.2018).

Mandeville, B. (1989). The fable of the bees. Londyn UK: Penguin.

Marshall, M. (2000). Luxury, economic development, and work motivation: David Hume, Adam Smith, and JR McCulloch. History of Political Economy, 32(3), 631-648.

McKeen, C. (2004). Swillsburg City Limits (The 'City Of Pigs': Republic 370C-372D). The Journal for Ancient Greek Political Thought, 21(1-2), 70-92.

McNeil, P., Riello, G. (2017). Historia luksusu. Warszawa: Bellona. 
Mozur, P. (2017). In Fight Against Fakes, Alibaba and Owner of Gucci Go From Adversaries to Partners. The New York Times. Pozyskano z https://www.nytimes.com/2017/08/03/business/alibaba-kering-fakes-luxury.html?ref=business (dostęp 13.05.2019).

Nosto (2019). Pozyskano z http://pages.nosto.com/sustainability-in-fashion-survey.html (dostęp 13.05.2019).

Paton, E. (2017). François-Henri Pinault, Kering Chief, on Why Green Is the New Black. New York Times. Pozyskano z https://www.nytimes.com/2017/01/25/fashion/franois-henri-pinault-kering-sustainability.html

Ramirez, S. (2019, June 05). Desire for sustainable fashion spans all generations. LuxuryDaily.

Rankabrand (2018). Pozyskano z www.rankabrand.com (dostęp 11.06.2018).

Seuring, S. \& Goldbach, M., (2006). Managing sustainability performance in the textile chain. W: S. Schaltegger i M. Wagner (Eds.), Sustainable Performance and Business Competitiveness (ss. 466 -477). Sheffield: Greenleaf Publishing.

Slater, S.F. (1997). Consumer culture and modernity. Oxford: Polity Press.

Stearns, P.N. (2006). Consumerism in world history: The global transformation of desire. New York: Routledge.

Stępień, B. (2019). Wartość luksusu. Perspektywa konsumentów i przedsiębiorstw. Warszawa: PWE.

Tallontire, A., Rentsendorj, E., \& Blowfield, M. (2001). Ethical Consumers and Ethical Trade: A Review of Current Literature. Policy Series 12, Natural Resources Institute, Kent.

Thach, E. C., Olsen, J. (2006). The role of service quality in influencing brand attachments at winery visitor centers. Journal of Quality Assurance in Hospitality \& Tourism, 7(3), 59-77.

Tsai, S.P. (2005). Impact of personal orientation on luxury-brand purchase value: An international investigation. International Journal of Market Research, 47, 429-454.

Tynan, C., McKechnie, S. \& Chhuon, C. (2010). Co-creating value for luxury brands. Journal of Business Research, 63(11), 1156-1163.

Van de Ven, B. (2008). An ethical framework for the marketing of corporate social responsibility. Journal of Business Ethics, 82(2), 339-352.

Vermeir, I. \& Verbeke W. (2006). Sustainable food consumption: exploring the consumer 'attitude behavioral intention. Journal of Agricultural and Environmental Ethics, 19, 169-194. doi:10.1007/s10806-005-5485-3

Voyer, B.G. \& Beckham, D. (2014). Can Sustainability Be Luxurious? a Mixed-Method Investigation of Implicit and Explicit Attitudes Towards Sustainable Luxury Consumption. Advances in Consumer Research, 42, 245-250.

Willems, K., Janssens, W., Swinnen, G., Brengman, M., Streukens, S. \& Vancauteren, M. (2012). From Armani to Zara: Impression formation based on fashion store patronage. Journal of Business Research, 65(10), 1487-1494.

Wong, A., Chung, Y. \& Zaichkowsky, J.L. (1999). Understanding luxury brands in Hong Kong. European Advances in Consumer Research, 4, 310-316.

Yang, Y., Han, H. \& Lee, P. (2017). An Exploratory Study of the Mechanism of Sustainable Value Creation in the Luxury Fashion Industry. Sustainability, 9(4), 483. http://doi.org/10.3390/su9040483 


\section{Tytuł $\mathrm{i}$ abstrakt $\mathbf{w}$ języku angielskim}

\section{Sustainability as a new category of value in luxury fashion? Results of qualitative research of international retailers}

The aim of the article is to show the evidence and causes of discrepancies in communication of sustainable development (as a complementary category of value) by the owners of brands and sellers in the luxury fashion industry. Qualitative research in the form of mystery shopping conducted between 2017 and 2018 in four cities: Singapore, Dubai, Paris and Berlin in stores of 10 global luxury fashion brands. Low consumer interest in sustainable development issues, combined with a lack of emphasis on implementing this idea in fashion houses, results in low awareness of retailers and communication of sustainable development as a category of values. The importance of sustainability as a complementary value of luxury is growing among consumers from Europe, the United States or Canada, while for the Far East it is still an irrelevant category for purchasing decisions. The emphasis on the promotion and the implementation of this idea is a function of both the interest of the consumer and the importance attached to it by the brand itself.

Keywords: $\quad$ sustainable development; luxury fashion; hidden shopping; communicating value for the consumer; luxury fashion sellers

JEL codes: D11, D12

\section{Autor}

\section{Beata Stępień}

Dr hab., prof. UEP, Katedra Zarządzania Międzynarodowego, Uniwersytet Ekonomiczny w Poznaniu; Autorka ponad 130 publikacji, o biznesie międzynarodowym, postrzeganiu wartości przez konsumenta i o biznesie luksusu.

Adres do korespondencji: Prof. dr hab. Beata Stępień, Uniwersytet Ekonomiczny w Poznaniu, al. Niepodległości 10, 61-875 Poznań, e-mail: beata.stepien@ue.poznan.pl

ORCID (1) http://orcid.org/0000-0002-0488-1146

\section{Podziękowania i finansowanie}

Artykuł jest wynikiem projektu finansowanego przez Narodowe Centrum Nauki DEC2013/11/B/HS4/01484.

\section{Prawa autorskie}

Ten artykuł został opublikowany na warunkach Creative Commons Uznanie autorstwa - Bez utworów zależnych (CC BY-ND 4.0 License) http://creativecommons.org/licenses/by-nd/4.0/

\section{Publikacja została wydana przez Uniwersytet Ekonomiczny w Krakowie}

